\title{
Investigating the Relationship between Professionalism and (Technical, Human, and Perceptual) Skills of Managers in Poly Akril Company of Iran from Experts' Viewpoint
}

\author{
Marzie Ghanbari
}

M.A. in Educational Administration

\begin{abstract}
Reza Hoveida
Associate Professor, Department of Educational sciences

Faculty of Educational sciences and Psychology, University of Isfahan, Iran
\end{abstract}

Seyed Ali Siadat

Associate Professor, Department of Educational sciences

Faculty of Educational sciences and Psychology, University of Isfahan, Iran

Received: December 26, 2015 Accepted: January 25, 2016 Published: May 21, 2016

doi:10.5296/ijhrs.v6i2.9429 URL: http://dx.doi.org/10.5296/ijhrs.v6i2.9429

\begin{abstract}
The objective of the present study is to investigate the relationship between managers' professionalism and (technical, human, and perceptual) skills in managers of Iran Poly Akril Company. The research is an applied one in terms of objectives, and a descriptive-correlational in terms of method. The population includes all experts working in the company in 2012 as 240 individuals among who 144 participants were selected using the stratified random sampling method proportionate to the population size as the sample size. The data collection instruments were two researcher-made questionnaires of Managers' skills containing 22 items and with the reliability coefficient as 0.96, and Professionalism containing 28 items and the reliability coefficient as 0.95 . Their validity was investigated and confirmed by professors and experts of management. Analyzing data was conducted at the two level of descriptive statistics (frequency, mean, SD, and presentation of tables and charts) and inferential statistics (one sample t-test, correlation coefficient, regression coefficient,
\end{abstract}


ANOVA, and F-test).

Keywords: Professionalism, Skills, Knowledge.

\section{Introduction}

Each person, in addition to his life, is responsible for the environment in which he lives or works. He should regulate his relation with the environment regarding the job he has in such a way that concurrent with creating morality, does his duties and responsibilities for the other people as appropriately as possible. Applying appropriate ethics at work causes that others trust you and results in the creation of social and economic opportunities; accessing all these factors require the observation of others' rights and doing job duties in the best way along with the adoption of morality. Nowadays, the most important variable in the success of organizations is professional ethics. Principles of professional ethics has high status and values which if one observes, they are effective on organizations and social norms. Professional ethics provides the power of self-control and self-improvement in individuals or in an organization. Observing professional ethics increases the capability of organization in business and reduces costs of the society and organizations. Professionalism was defined by Schon (1982) for the first time. He called professionalism as a model of "Technical Rationality". Professional activities include solving instrumental problems which are adopted by scientific theories and techniques. Professionalism in general can be illustrated as adoption of scientific knowledge in general and solving problems and challenging barriers in particular. Therefore, it can be presented using conventional and institutionalized methods and models (Noordegraaf, 2007), for a long time, sociologists of professional jobs had a different interpretation of professionalism rather than considered it as a particular instrument for organizing activities and controlling workers with real advantages for both employers and customers (Evetts, 2011).

Freidson (2001) describes professionalism as "the third logic standing against the logics of the market and enterprises" and emphasizes the significance of keeping professionalism as a certain and different working state or situation and controlling workers in the sector of public services. This interpretation of professionalism has a long history and in which professionalism is considered as a professional value. But notions of a professional person and professionalism have been ever changing. A professional person works in a very large organizational scale and sometimes he works in international professional corporations (Nordegraf, 2007).

Boland and Temple (2004) argue that the concepts of professional and professionalism as well as how they are measured over time have evolved and changed (Black and Gutierrez, 2011). Traditional and modern understanding of professionalism are related to some standards which usually are determined by professional individuals. In this perception, a professional individual is loyal to an ideology or a set of values to the extent that his performance guides him in line with performing organizational duties.

Here, those who are professional usually are put in the professional associations and 
organization and individuals in organization become members of these associations via issuing licenses, certifications, or membership. These interpretations have changed since the beginning of the present century, namely when firstly professionalism mainly are along with distinctive and certain orientations, and then they appeared using organizational standard's and controls. Recently, professionalism is considered as the dominant characteristics of a professional individual. Nowadays, modern workforces' lifelong learning is emphasized and the continuous development of a person is considered as one of the main components of a professional individual (Friedman and Philips, 2004 as cited in Black and Gutierrez, 2011).

According to Kurana (2007), professionalism is an agreement which is created for the definition of a profession and results in engendering professional associations. Nowadays, professionalism results in the establishment of professional syndicates and formal and specialized associations. In addition, professions accept their particular commitments and responsibilities in terms of their degree of formality and the creation of professional associations formally and then, they dictate them to their members. Members of the profession agree that observe their social responsibilities by observing professional ethics. Members of professions consider themselves as loyal to social duties and responsibilities and swear to create and reinforce such commitment when they enter and become members of associations. Professionalism, by reinforcing professional morality, is one of the most effective mechanisms of internal control or self-control and is a continuum on the one extreme, ideal professional values and on the other one, the dispersion or lack of professional values are observed.

Skill refers to the trainable abilities of a person which are reflected in performance and duties. Therefore, by skill, it means the ability of applying personal knowledge and experience effectively (Alagheband, 2002).

Wu et al. (1993) argue the classification of managers' skills from the viewpoints of Sandwich, Mandt, and Duffield as follows:

Sandwich state that managers should have intellectual or creative, leadership, interpersonal, and technicalskills in order to be able to use them in working situations for achieving its effective results. Intellectual or creative skills include an expansive domain of an organization and include ranging from creative skills to planning. Interpersonal skills include communicative, coordinative and social skills. In addition, Mandt (1979) advises technical and professional, interpersonal, and executive skills for managers. In addition, Duffield (1994) determines analytical, planning, organizational, and control abilities for managers.

Eltantawy et al. (2009) explains managers' skills from the viewpoint of Kolchin, Giunipero, and Murphy as follows:

Golchin and Ginipour (2914) define four sets of skills for managers as follows:

1. Technical skills

2. Executiveskills

3. Interpersonal or intergroupskills 
4. Personalskills

Murphy (1995) suggests skills of negotiation, management power, computer knowledge, and mathematics.

Carr \&Smeltzer (2000), name only three sets of skills:

1. Technical skills such as designing and computer

2. Behavioral skills such as social and supportive skills

3. Skill techniques such as time management and organizational skills.

Perce (2000) considers strategic skills, process management, team skills, decision-making, behavioral skills, negotiation skills, and qualitative skills for managers of companies.

\section{Methodology}

The aim of the present study is to investigate professionalism and the three technical, human, and perceptual skills of managers of Poly Akril Company of Iran from experts' viewpoint. The research hypotheses were developed and investigated with considering components of professionalism and the three skills of managers and their demographic characteristics (age and years of service). The research method is a descriptive-correlational one and the population included all experts working in the company who were 240 individuals in 2012 . Regarding the stratified random sampling method proportionate to the population, 144 participants were selected as the sample size and 111 questionnaires were returned. Using Cronbach's alpha, the reliability of the researcher-made questionnaire of professionalism was calculated as 0.95 and the reliability of the researcher-made questionnaire of the three skills of managers was obtained as 0.96 . Then, analyzing data was conducted at the two level of descriptive statistics (frequency, mean, SD, and presentation of tables and charts) and inferential statistics (one sample t-test, correlation coefficient, regression coefficient, ANOVA, and F-test).

\section{Research Findings}

The main hypotheses: there is a significant correlation between professionalism and the three technical, human, and perceptual skills of managers of Poly Akril Company of Iran.

Table 1: testing correlation between professionalism and (technical, human, and perceptual) skills of managers

\begin{tabular}{|l|l|l|l|}
\hline Resource & Frequency & $\begin{array}{l}\text { Pearson correlation } \\
\mathrm{R}\end{array}$ & Sig. \\
\hline $\begin{array}{l}\text { professionalism and } \\
\text { managers skills } \\
\text { (technical, human, } \\
\text { and perceptual) }\end{array}$ & 111 & 0.855 & 0.000 \\
\hline
\end{tabular}




\section{Macrothink}

The above table indicate that the relationship between variables of professionalism and (technical, human, perceptual) skills of managers of Poly Akril Company of Iran. As observed, the correlation coefficient $(r=0.855)$ at the significance level $(p=0.05)$ is significant and the direction is direct and positive, i.e. the higher the scores of professionalism are, the higher (technical, human, perceptual) skills of managers will be.

Hypothesis 1: there is a significant correlation between independence and technical, human, and perceptual skills of managers of Poly Akril Company of Iran.

Table 2: testing correlation between independence and (technical, human, and perceptual) skills of managers

\begin{tabular}{|l|l|l|l|}
\hline Resource & Frequency & $\begin{array}{l}\text { Pearson correlation } \\
\mathrm{R}\end{array}$ & Sig. \\
\hline $\begin{array}{l}\text { Independence and } \\
\text { (technical, human, } \\
\text { and perceptual) skills } \\
\text { of managers }\end{array}$ & 111 & 0.620 & 0.000 \\
\hline
\end{tabular}

Table 2 indicate that the relationship between variables of independence and (technical, human, perceptual) skills of managers of Poly Akril Company of Iran. As observed, the correlation coefficient $(\mathrm{r}=0.620)$ at the significance level $(\mathrm{p}=0.05)$ is significant and the direction is direct and positive, i.e. the higher the scores of independence are, the higher (technical, human, perceptual) skills of managers will be.

Hypothesis 2: there is a significant correlation between knowledge and technical, human, and perceptual skills of managers of Poly Akril Company of Iran.

Table 3: testing correlation between knowledge and (technical, human, and perceptual) skills of managers

\begin{tabular}{|l|l|l|l|}
\hline Resource & Frequency & $\begin{array}{l}\text { Pearson correlation } \\
\mathrm{R}\end{array}$ & Sig. \\
\hline $\begin{array}{l}\text { Knowledge and } \\
\text { (technical, human, } \\
\text { and perceptual) skills } \\
\text { of managers }\end{array}$ & 111 & 0.723 & 0.000 \\
\hline
\end{tabular}




\section{Macrothink}

Table 3 indicate that the relationship between variables of knowledge and (technical, human, perceptual) skills of managers of Poly Akril Company of Iran. As observed, the correlation coefficient $(\mathrm{r}=0.723)$ at the significance level $(\mathrm{p}=0.05)$ is significant and the direction is direct and positive, i.e. the higher the scores of knowledge are, the higher (technical, human, perceptual) skills of managers will be.

Hypothesis 3: there is a significant correlation between competency and technical, human, and perceptual skills of managers of Poly Akril Company of Iran.

Table 4: testing correlation between the competency and (technical, human, and perceptual) skills of managers

\begin{tabular}{|l|l|l|l|}
\hline Resource & Frequency & $\begin{array}{l}\text { Pearson correlation } \\
\mathrm{R}\end{array}$ & Sig. \\
\hline $\begin{array}{l}\text { professionality and } \\
\text { (technical, human, } \\
\text { and perceptual) skills } \\
\text { of managers }\end{array}$ & 111 & 0.714 & 0.000 \\
\hline
\end{tabular}

Table 4 indicate that the relationship between variables of competency and (technical, human, perceptual) skills of managers of Poly Akril Company of Iran. As observed, the correlation coefficient $(\mathrm{r}=0.714)$ at the significance level $(\mathrm{p}=0.05)$ is significant and the direction is direct and positive, i.e. the higher the scores of competency are, the higher (technical, human, perceptual) skills of managers will be.

Hypothesis 4: there is a significant correlation between professionality and technical, human, and perceptual skills of managers of Poly Akril Company of Iran.

Table 5: testing correlation between professionality and (technical, human, and perceptual) skills of managers

\begin{tabular}{|l|l|l|l|}
\hline Resource & Frequency & $\begin{array}{l}\text { Pearson correlation } \\
\mathrm{R}\end{array}$ & Sig. \\
\hline $\begin{array}{l}\text { Professionality and } \\
\text { (technical, human, } \\
\text { and perceptual) skills } \\
\text { of managers }\end{array}$ & 111 & 0.697 & 0.000 \\
\hline
\end{tabular}




\section{Macrothink}

International Journal of Human Resource Studies

ISSN 2162-3058 2016, Vol. 6, No. 2

Table 5 indicate that the relationship between variables of professionality and (technical, human, perceptual) skills of managers of Poly Akril Company of Iran. As observed, the correlation coefficient $(\mathrm{r}=0.697)$ at the significance level $(\mathrm{p}=0.05)$ is significant and the direction is direct and positive, i.e. the higher the scores of professionality are, the higher (technical, human, perceptual) skills of managers will be.

Hypothesis 5: there is a significant correlation between accountability and technical, human, and perceptual skills of managers of Poly Akril Company of Iran.

Table 6: testing correlation between accountability and (technical, human, and perceptual) skills of managers

\begin{tabular}{|l|l|l|l|}
\hline Resource & Frequency & $\begin{array}{l}\text { Pearson correlation } \\
\mathrm{R}\end{array}$ & Sig. \\
\hline $\begin{array}{l}\text { accountability and } \\
\text { (technical, human, } \\
\text { and perceptual) skills } \\
\text { of managers }\end{array}$ & 111 & 0.771 & 0.000 \\
\hline
\end{tabular}

Table 6 indicate that the relationship between variables of accountability and (technical, human, perceptual) skills of managers of Poly Akril Company of Iran. As observed, the correlation coefficient $(\mathrm{r}=0.697)$ at the significance level $(\mathrm{p}=0.05)$ is significant and the direction is direct and positive, i.e. the higher the scores of accountability are, the higher (technical, human, perceptual) skills of managers will be.

Hypothesis 6: there is a significant correlation between supports and technical, human, and perceptual skills of managers of Poly Akril Company of Iran.

Table 7: testing correlation between supports and (technical, human, and perceptual) skills of managers

\begin{tabular}{|l|l|l|l|}
\hline Resource & Frequency & $\begin{array}{l}\text { Pearson correlation } \\
\mathrm{R}\end{array}$ & Sig. \\
\hline $\begin{array}{l}\text { supports and } \\
\text { (technical, human, } \\
\text { and perceptual) skills } \\
\text { of managers }\end{array}$ & 111 & 0.532 & 0.000 \\
\hline
\end{tabular}




\section{Macrothink}

Table 7 indicate that the relationship between variables of supports and (technical, human, perceptual) skills of managers of Poly Akril Company of Iran. As observed, the correlation coefficient $(\mathrm{r}=0.532)$ at the significance level $(\mathrm{p}=0.05)$ is significant and the direction is direct and positive, i.e. the higher the scores of supports are, the higher (technical, human, perceptual) skills of managers will be.

Hypothesis 7: there is a significant correlation between cooperation and technical, human, and perceptual skills of managers of Poly Akril Company of Iran.

Table 8: testing correlation between cooperation and (technical, human, and perceptual) skills of managers

\begin{tabular}{|l|l|l|l|}
\hline Resource & Frequency & $\begin{array}{l}\text { Pearson correlation } \\
\mathrm{R}\end{array}$ & Sig. \\
\hline $\begin{array}{l}\text { cooperation and } \\
\text { (technical, human, } \\
\text { and perceptual) skills } \\
\text { of managers }\end{array}$ & 111 & 0.739 & 0.000 \\
\hline
\end{tabular}

Table 8 indicate that the relationship between variables of cooperation and (technical, human, perceptual) skills of managers of Poly Akril Company of Iran. As observed, the correlation coefficient $(\mathrm{r}=0.739)$ at the significance level $(\mathrm{p}=0.05)$ is significant and the direction is direct and positive, i.e. the higher the scores of cooperation are, the higher (technical, human, perceptual) skills of managers will be.

Hypothesis 8: there is a significant correlation between commitment and technical, human, and perceptual skills of managers of Poly Akril Company of Iran.

Table 9: testing correlation between the commitment and (technical, human, and perceptual) skills of managers

\begin{tabular}{|l|l|l|l|}
\hline Resource & Frequency & $\begin{array}{l}\text { Pearson correlation } \\
\mathrm{R}\end{array}$ & Sig. \\
\hline $\begin{array}{l}\text { commitment and } \\
\text { (technical, human, } \\
\text { and perceptual) skills } \\
\text { of managers }\end{array}$ & 111 & 0.696 & 0.000 \\
\hline
\end{tabular}




\section{Macrothink}

International Journal of Human Resource Studies

ISSN 2162-3058 2016, Vol. 6, No. 2

Table 9 indicate that the relationship between variables of commitment and (technical, human, perceptual) skills of managers of Poly Akril Company of Iran. As observed, the correlation coefficient $(\mathrm{r}=0.696)$ at the significance level $(\mathrm{p}=0.05)$ is significant and the direction is direct and positive, i.e. the higher the scores of commitment are, the higher (technical, human, perceptual) skills of managers will be.

\section{The suggested research model}

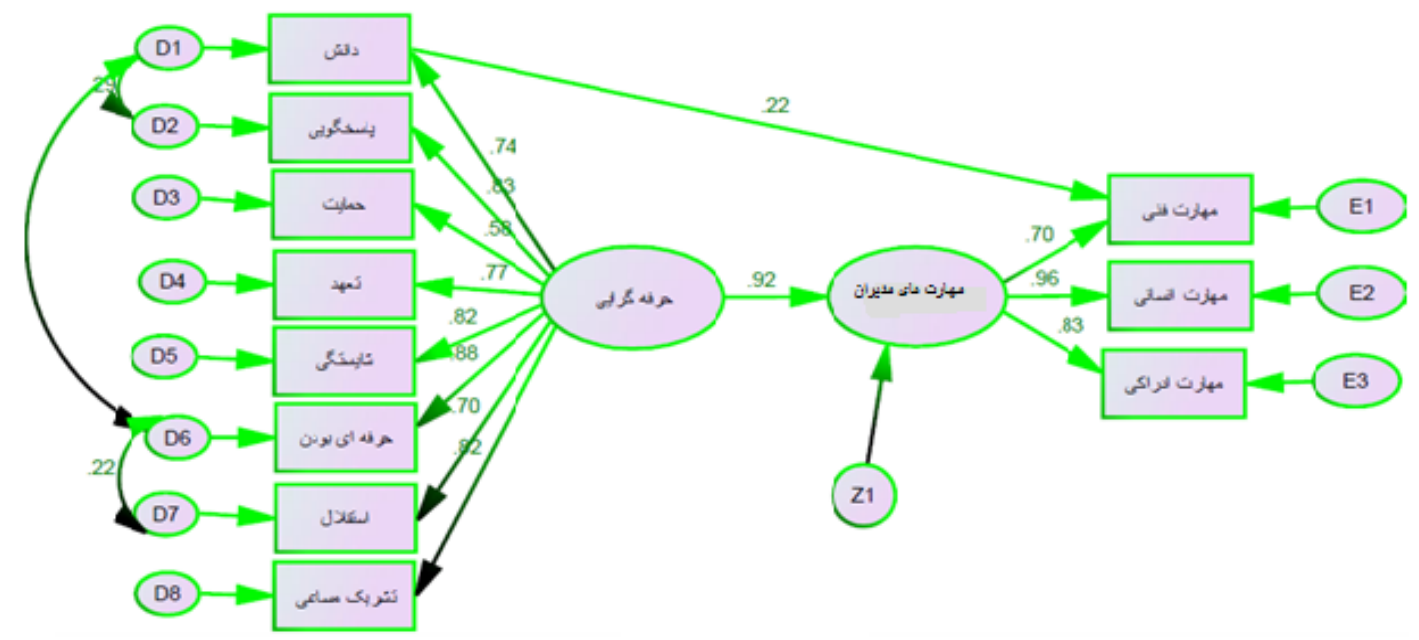

Figure 1 the output model extracted from Amos software for the effect of the variable of professionalism on the three (technical, human, perceptual) skills of managers

Table 10: non-standard regression coefficient of managers' professionalism on their three technical, human, perceptual skills

\begin{tabular}{|c|c|c|c|c|c|c|c|}
\hline $\begin{array}{l}\text { Result } \\
\mathrm{S}\end{array}$ & $\mathrm{P}$ & $\begin{array}{l}\text { Critical } \\
\text { value }\end{array}$ & $\begin{array}{l}\text { Regressi } \\
\text { on } \\
\text { coefficie } \\
\text { nt }\end{array}$ & & & & Row \\
\hline $\begin{array}{l}\text { Confir } \\
\text { med }\end{array}$ & $* * *$ & 0.123 & 0.838 & $\begin{array}{l}\text { (technical, } \\
\text { human, } \\
\text { perceptual) } \\
\text { skills }\end{array}$ & $\leftarrow$ & Professionalism & 1 \\
\hline $\begin{array}{l}\text { Confir } \\
\text { med }\end{array}$ & & & 1 & Knowledge & & Professionalism & 2 \\
\hline $\begin{array}{l}\text { Confir } \\
\text { med }\end{array}$ & $* * *$ & 0.115 & 1.21 & Accountability & $\leftarrow$ & Professionalism & 3 \\
\hline
\end{tabular}




\begin{tabular}{|c|c|c|c|c|c|c|c|}
\hline $\begin{array}{l}\text { Confir } \\
\text { med }\end{array}$ & $* * *$ & 0.154 & 0.93 & Supports & $\leftarrow$ & Professionalism & 4 \\
\hline $\begin{array}{l}\text { Confir } \\
\text { med }\end{array}$ & $* * *$ & 0.128 & 1.05 & Commitment & $\leftarrow$ & Professionalism & 5 \\
\hline $\begin{array}{l}\text { Confir } \\
\text { med }\end{array}$ & $* * *$ & 0.142 & 1.23 & Competency & $\leftarrow$ & Professionalism & 6 \\
\hline $\begin{array}{l}\text { Confir } \\
\text { med }\end{array}$ & $* * *$ & 0.170 & 1.38 & Professionality & $\leftarrow$ & Professionalism & 7 \\
\hline $\begin{array}{l}\text { Confir } \\
\text { med }\end{array}$ & $* * *$ & 0.142 & 1.048 & Independence & $\leftarrow$ & Professionalism & 8 \\
\hline $\begin{array}{l}\text { Confir } \\
\text { med }\end{array}$ & $* * *$ & 0.134 & 1.18 & Cooperation & $\leftarrow$ & Professionalism & 9 \\
\hline $\begin{array}{l}\text { Confir } \\
\text { med }\end{array}$ & & & 1 & Technical skills & $\leftarrow$ & $\begin{array}{l}\text { (technical, human, } \\
\text { perceptual) skills }\end{array}$ & 10 \\
\hline $\begin{array}{l}\text { Confir } \\
\text { med }\end{array}$ & & 0.162 & 1.44 & Human skills & $\leftarrow$ & $\begin{array}{l}\text { (technical, human, } \\
\text { perceptual) skills }\end{array}$ & 11 \\
\hline $\begin{array}{l}\text { Confir } \\
\text { med }\end{array}$ & $* * *$ & 0.163 & 1.32 & $\begin{array}{l}\text { Perceptual } \\
\text { skills }\end{array}$ & $\leftarrow$ & $\begin{array}{l}\text { (technical, human, } \\
\text { perceptual) skills }\end{array}$ & 12 \\
\hline $\begin{array}{l}\text { Confir } \\
\text { med }\end{array}$ & $\begin{array}{l}0.00 \\
2\end{array}$ & 0.07 & 0.21 & Technical skills & $\leftarrow$ & Knowledge & 13 \\
\hline
\end{tabular}

As observed in the above table, all non-standard regression weights including gamma parameter (the effect of the external variable on the internal one) and factor loadings in the definition of variables of professionalism and the three technical, human, perceptual skills of managers indicate that all factors have positive effects and the significant level lower than 0.05 shows the confirmation of the effect of all factors. 


\section{IIMacrothink}

International Journal of Human Resource Studies

ISSN 2162-3058 2016, Vol. 6, No. 2

Table 11: standard regression coefficients and factor loadings of variables of the three technical, human, perceptual skills of managers

\begin{tabular}{|c|c|c|c|c|}
\hline $\begin{array}{l}\text { Regression } \\
\text { coefficient }\end{array}$ & & & & Row \\
\hline 0.92 & $\begin{array}{l}\text { (technical, human, } \\
\text { perceptual) skills }\end{array}$ & $\leftarrow$ & Professionalism & 1 \\
\hline 0.74 & Knowledge & $\leftarrow$ & Professionalism & 2 \\
\hline 0.83 & Accountability & $\leftarrow$ & Professionalism & 3 \\
\hline 0.58 & Supports & $\leftarrow$ & Professionalism & 4 \\
\hline .77 & Commitment & $\leftarrow$ & Professionalism & 5 \\
\hline 0.82 & Professionality & $\leftarrow$ & Professionalism & 6 \\
\hline 0.88 & Independence & $\leftarrow$ & Professionalism & 7 \\
\hline 0.70 & Cooperation & $\leftarrow$ & Professionalism & 8 \\
\hline 0.82 & Technical skills & $\leftarrow$ & $\begin{array}{l}\text { (technical, human, } \\
\text { perceptual) skills }\end{array}$ & 9 \\
\hline 0.70 & Human skills & $\leftarrow$ & $\begin{array}{l}\text { (technical, human, } \\
\text { perceptual) skills }\end{array}$ & 10 \\
\hline 0.96 & Perceptual skills & $\leftarrow$ & $\begin{array}{l}\text { (technical, human, } \\
\text { perceptual) skills }\end{array}$ & 11 \\
\hline 0.83 & Perceptual skills & $\leftarrow$ & $\begin{array}{l}\text { (technical, human, } \\
\text { perceptual) skills }\end{array}$ & 12 \\
\hline 0.22 & technical skills & $\leftarrow$ & Knowledge & 13 \\
\hline
\end{tabular}

Table 11 indicates regression coefficient and factor loadings of professionalism and the three technical, human, perceptual skills of managers. As indicated in the above table, the effect of professionalism on the three technical, human, perceptual skills of managers is 0.92 which can be said that professionalism explains $0.84 \%$ of variations related to the three technical, human, perceptual skills of managers. 


\section{Discussion and Conclusion}

The results of the present study indicated that there is a positive and significant professionalism and technical, human, and perceptual skills of managers of Poly Akril Company ( $\mathrm{r}=0.85$, and $\mathrm{p}=0.05)$, it means that the higher the scores professionalism are, the higher the scores of the three technical, human, perceptual skills of managers will be. In addition, the results indicated that about $0.76 \%$ of the variations of the three technical, human, perceptual skills of managers is related to variables of professionalism and the rest is related to other variables. In addition, the relationship of other components of professionalism with skills is confirmed.

Scully et al. (1999), investigate3d the inability of managers for determining knowledge and skills in them. Their study identified the staff unable in management. First of all, a list of unable managers' skills were submitted to 800 employees and 311 of them returned the list; then analysis of factors of this list with the subject of knowledge and skill in three fields of fundamental management, vocational rehabilitation factors and factors useful in counseling. The results indicated that there are a lot of differences in the significance of this knowledge and skills of these employees regarding individuals' professional classifications and environments. In addition, there are a lot of differences in the reported readiness in fields of knowledge and skills considering professional classifications.

$\mathrm{Wu}$ et al. (2004), in their study conducted on the significance of activities conducted by managers of IS, investigated the relationship between management activities and skills. In this research, a questionnaire containing two sections including basic information and management activities and skills was used. Then, using the Likert scale (strongly disagree, disagree, no idea, agree, strongly agree), they investigated respondents' ideas. Finally, their hypothesis stating that there is a correlation between managers' activities and their skills was confirmed and they concluded that in general, management skills are required for managers' effective activities.

Praganidis\&Mentaz (2006), in a research titled as "competency-based management: a framework of systems and approaches", investigated key concepts of competency-based management and the results indicated that standard grounds by rejecting competency patterns, is to create technologies for playing an important role in completing competency-based management systems.

Spendlove (2007), in a research titled as "competencies required for effective leadership excellence in education", investigated the role of Deans of universities and their competencies for leadership of higher education and concluded that the most common competencies are reputation, experience, personal skills and human aspects (negotiation, delegation, motivation, coaching, supervision and control, team building and communication).

Pilly (2008) in a research titled as "Hospital management competencies defined in the public and private sectors" in South Africa, identified 39 management competencies for mangers. The results indicated that managers of private and public sectors feel that people-oriented 
management and self-management skills are among the most valuable competencies for effective and efficient management in hospitals.

Nwokan\&Ahiavzv (2008), conducted a research titled as "the effect of management competencies as a result of marketing managers in businesses" and concluded that there is a strong correlation between management competencies and effectiveness of marketing. In addition, they concluded that management competencies results in effective marketing in commercial organizations.

Sambasivan et al. (2009) conducted a research with the aim of studying the role of personal characteristics, management skills and skills of identifying opportunities in Malaysian companies. They developed a questionnaire and sent its copies to 1275 small and medium-sized companies. The results are as follows: 1. Skills of identifying opportunities act as an absolute intermediate. 2. Skills of identifying opportunities are effective in participatory performances. 3. There is a relationship between the accuracy and awareness as well as personal characteristics and participatory performances. 4. Previous accuracy and knowledge have relationship with managers' skills and participatory performances.

Lumlertgul et al. (2009) in Thailand and in a project for training professionalism in medicine, used 5 movies with themes about professionalism and 20-30 students in each show times as participants. After watching, participants were questioned and two students negotiated with each other about professionalism for 60 minutes. The results indicated that professionalism causes the development of critical thinking and moral arguments.

Hwang et al. (2009), in their studies titled as "professionalism as the main factor influencing job satisfaction among nurses in Korea and China".A questionnaire was developed for measuring professionalism and job satisfaction of nurses and analyzing the results indicated that professionalism is a general factor affecting job satisfaction among nurses in Korea and China. In addition, professionalism has a positive relationship with job satisfaction in the two groups. Demographic factors and characteristics such as age, status, and the place of work were effective, but they were significant only among Korean nurses and professionalism was the most important factor in job satisfaction in the two groups of Korean and Chinese nurses.

Baumann and Kolotylo (2009), in their research conducted in Canada, aimed at describing key features of professionalism and environmental factors using a questionnaire which was designed based on factors such as Professionalism (knowledge, competence, professionalism and accountability, advocacy, collaboration, commitment) and environmental factors (performance monitoring, quality of work life, support, professional, government, and environmental and cultural atmosphere). It indicated that professionalism and environmental characteristics are effective on working life.

Elliot et al. (2009) in their study conducted with the support of University of California titled as "shaping professionalism in medical students" aimed at measuring the development of the path of professionalism in the first 2 years of the curricula of medical sciences. Using a certain curriculum conducted during 7 years indicated that more than $60 \%$ of students' reports illustrated skills related to the path of objectives. 
Chansiri and Srisaard (2009) conducted research titled as "competencies necessary to support line managers in state universities in Thailand". The sample included 24 universities and 920 executive managers as well as 300 staff support managers. The results indicated that fundamental competencies necessary for support managers are teamwork, planning and management, leadership, creative thinking and ethics.

Finn and Garner (2010) in a research with the aim of explaining that how medical students perceive professionalism and apply them. $72 \mathrm{BA} / \mathrm{BSc}$ students participated in an experiment. The results of the experiment indicated that students' perception of professionalism help them to learn issues with more efficiency.

Borgstrom and Cohn (2010), in their studies conducted in Cambridge University, aimed at investigating how senior medical students and the changes in values of professionalism with current values via dimensions of hidden curriculum appear. Using qualitative studies and detailed and interpretative interviews with students, they concluded that students emphasize patient-centeredness and general healthcare which is equivalent to contemporary ideas of professionalism in medicine. In moral considerations (the interaction between patients, physicians and mental limitations), there were more conflicts.

Jang and Yan(2010), in a study conducted in University of New York on medical professionalism among Chinese medical students aimed at explaining how is primary knowledge of medical students about characteristics of good and professional students. A public and a non-pubic test were administered about identifying these characteristics (in the public test, 973 and in the non-public test, 1730 students participated) and three main features of morality, skills, and personality were extracted and the results indicated that these three features are effective on physicians' professionalism.

Zakari and Alkhamis (2010), in a research conducted on the perception of nurses from Saudi Arabia, selected 343 nurses from different hospitals of Saudi Arabia and using the perception of professionalism questionnaire completed by nurses, indicated that their perceptions of professionalism is low.

Most researches conducted on professionalism have been about medical affairs and issues related, therefore, the present study were to investigate the issue of professionalism in management which has been considered by scholars. The following suggestions and recommendations presented as follows have been based on the findings of the results of the present research about officials of Poly Akril Company of Iran:

1. The results of the present study indicated that there is a significant and positive correlation between professionalism and the three skills of managers in the company. According to these results, before employing managers, the mentioned company should consider technical skills (ability to work with facilities and equipment of the company), human skills (ability to work with persons and employees), and perceptual skills (systemic thinking of these individuals and ability to perceive the complications of the whole company) by administering written tests and psychological interviews by experts. After employing them, using expert and experienced staff in the company and 


\section{Macrothink Institute ${ }^{\text {tm }}$}

educated experts aware of the mechanism of systems and equipment, the company can train them. In addition, it can use experts and psychologists for holding courses and lectures about skills of human relations and the positive and proper effects which these skills can have in their personal life, as well as training the holistic and comprehensive thinking and attitudes towards issues.

2. Regarding the results of the present study stating that knowledge has the highest correlation with technical skill as one of the components of managers' skills, the company should increase managers' knowledge of mechanical and power machinery in its educational courses for working with equipment and systems. For increasing the effectiveness of these courses, both experts of the company and educated engineers of other fields should be used.

3. Other results of the study indicated that there is a high correlation between accountability and human skills. Therefore, it can be suggested that by delegating specific authorities to managers and investigating their accountability to the delegated authorities, their sense of accountability can be enhanced from higher ranks. In addition, some surveys should be conducted by experts among employees to investigate the degree of managers' accountability. This issue causes that mangers feel that their authorities and duties are evaluated. In addition, holding Question and answer sessions between managers and employees for clarifying managers' and employees' expectations can be effective in this regard.

4. The component of managers' professionality has the highest effect on defining professionalism. Based on the results of the study, the company should determine standards for managers, and with evaluation based on these standards and criteria, it should identify professional managers, and by providing financial and welfare facilities for them and introducing these managers via newspapers and the website of the company, encourage them and make professionality as a competitive issue in order that other managers start to be professional in a healthy competition in line with their personal objectives and those of the company.

\section{References}

Baumann, A., \&Kolotylo, C. (2009). The Professionalism and environmental factors in the work Place. Journal of Advanced Nursing. 65 (10), 2216- 2228.

Black, R., \& Gutierrez, O. (2011). AsemanticAnalysis is approach for assessing Professionalism using free-form text entered on line, Published by Elsevier ltd., computer Behavior, 17, 2249- 2262.

Borgstrom, E., Cohn, S., \& Barclay, S. (2010). Medical professionalism: conflicting values for tomorrow's Doctors. Journal Gen Intern Medical, 25 (12), 1330- 1336.

Carr, A.S, Smeltzer, L. R. (2000). An. Empirical study of the relationship among purchasing skills and strategic purchasing, financial, performance, and supplier responsiveness. Journal 
of supply chain Management, 36(3), 40- 54.

Chansiri, W., \&Srisa, A. (2009). Core competencies of Public universities supporting line administrators in Thailand. The social science, 4, 1, 128-132.

Dragandis, F., \&Mentaz, G. (2006). Competency based Management: are view of systems and approaches, information Management \& computer security, 14 (1), 51- 84.

Elliot, D., May, W. B., \&Schaft, P. (2009). Shaping professionalism in pre-clinical Medical students Professionalism and the practice of Medicine. Medical Teacher, 31, 295- 302.

Eltantawy, R. A, Giunipero, L. fox, G. L. (2009). A strategic skill based model of supplier in integration and its effect on supply management Performance. Journal of industrial Marketing.

Evetts, J. (2011). Anew Professionalism? Challenges and opportunities, Sage Publication, 59 (4), 406- 422.

Hersey, P. and Blanchard, K. (2005). Organizational Behavior Management, Translation A. Alaghehband (Trans.), Tehran: Amir Kabir.

Hwang, J., Lou, F., \&Ltan, S. (2009). Professionalism: The Major factor influencing of satisfaction among Korean and Chinese nurses. Journal of International Council of Nurses, 56, 313- 318 .

Jang. S., \& Yan, XiE, X. (2010). Initial knowledge of Medical Professionalism among Chinese Medical students. Journal of Medical Teacher. 32, 961- 970.

Khurana, R., Nohria, N., \&Pnrice, D. (2005). Is BusinessManagement a profession? Http: //hbswk. Hts. eduliten $/ 4$ 650htm/.

Lumlertgul, N., Kijpaisalratana, N., \&Pityaratstian, N., (2009). A Pilot student using movies to help students Learn Medical Professionalism. Chulalongkorn University, Faculty of Medicine. 31, 327- 332.

Norrdegraaf, M. (2007). From "Pure" to "Hybrid" Professionalism Present -Day Professionalism in Ambiguous Public Domains, Sage publications, 39 (6), $761-785$.

Nwokah, N. G., \&Ahiauzu, A. (2008). Managerial competencies and Marketing effectiveness in corporate organizations in Nigeria, Journal of Management development, 27, 8, 858- 878.

Pillay, R. (2008). Managerial competencies of Hospital Managers in south Africa, Human Resources for Health, 6, 4, 1-7.

Sambasivan, M. Abdul, M. Yusop, Y. (2009). Impact of personal qualities and management skills of entrepreneurs on venture performance in Malaysia: opportunity recognition skill as a mediating factor, technovation Journal, 29, 798 - 805.

Scully, S. M, Habeck, R.v., Leahy, M. J. (1999). Knowledge and skill Areas Associated with Disability Management Practice for Rehabilitation counselors, Michigan state university, 43 (1), 20-29. 


\section{Macrothink}

International Journal of Human Resource Studies

ISSN 2162-3058 2016, Vol. 6, No. 2

Spendlove, M. (2007). Competencies for effective leadership in higher education, International Journal of Educational Management, 21, 5, 407- 417.

Stoof, A., Morten, S. R., Van Merrinebeer, J. G., \&Bastiaens, T. J. (2002). The Boundary Approach of Competence: A constructivist Aid for understanding and using the concept of competence. Human Resource Development Review, 345-365.

Wu, J. H, Chen, Y.C., Lin, H. (2004). Developing a set of Management needs for is managers: a study of necessary managerial activities and skills, information of Management Journal, 41, 413- 429.

Zakari, N. M., Khamis, N., \&Hamadi, H. Y. (2010). Conflict and Professionalism: perfections among nurses in Saudi Arabia. Journal of International Nursing Review, 57, 297- 304.

\section{Copyright Disclaimer}

Copyright for this article is retained by the author(s), with first publication rights granted to the journal.

This is an open-access article distributed under the terms and conditions of the Creative Commons Attribution license (http://creativecommons.org/licenses/by/3.0/). 